\title{
Osmanlılarda Resimli Silsilenâme Geleneği: 16. Yüzyıl Sonu-17. Yüzyıl Başları
}

\author{
Dr. Öğr. Üyesi Abdurrahim AYĞAN \\ Şırnak Üniversitesi \\ GSF, Resim Bölümü \\ aaygan@hotmail.com \\ ORCID: 0000-0003-1717-021X
}

\begin{abstract}
Öz
Osmanlı hanedanının soyu erken dönem tarih kitapları içerisinde yer almasına karşın, soyağacı tarzında şematik biçimli dünya tarihi tarzındaki ilk silsilenâme II. Bayezid (1481-1512) dönemine tarihlendirilir. Resimsiz ve küçük boyutlu olan bu eserle birlikte bu türün Osmanlılarda geç dönemlere kadar gelişimini sürdürdüğünü söylemek mümkündür. Devletin imparatorluğa dönüştüğü ve politik kimliğinin evrildiği Kanuni döneminde bu türe ilginin arttığı, silsilenâmelerin çeşitlendiği görülmektedir. Derviş Mehmed bin Ramazan, Yusuf bin Abdullatif ve Şerif Şefii gibi tarihçiler gerek rulo gerekse de kitap şeklindeki silsileleri bu dönemde vücuda getirmişlerdir. 16. yüzyıl sonları ile 17. yüzyıl başlarında bu türde sıra dışı bir hareketlilik dikkati çeker. 16 yüzyıl ortalarında sarayda hazılanan örneklerden farklı olarak sultanların portre madalyonlarını içeren bu silsilenâmeler, Osmanlının bir eyaleti olan Bağdat'ta üretilmiştir. Bağdatı silsile tasarımcıları bu eserlerde radikal bir değişikliğe giderek yatay yerine dikey soy çizgilerine dayanan bir modeli benimsemiştir. Bunun yanı sıra her biri tek elden çıkmış gibi standart tasarım ve kurguya sahip olmaları bu eser grubunu farklı kılmaktadır. Bu sebeple aynı tarihlerde belirli motivasyonla hazılanan silsilelerin bir bütün olarak ele alınması gerekmektedir. Bu çalışmada odaklandığımız husus resimli nüshalar temel alınarak Bağdat'ta hazırlanan bu eserleri kurgu ve tasarım açısından incelemek ve İslam dünyasında hazırlanan önceki örnekler arasındaki farkllıkları ortaya koymaktır.
\end{abstract}

Anahtar Kelimeler: osmanlı silsilesi, soyağacı, minyatür, islam resim sanatı, osmanlı el yazmaları

Ayğan, A. (2020). Osmanlılarda Resimli Silsilenâme Geleneği: 16. Yüzyıl sonu-17. Yüzyıl Başları. ARTS: Artuklu Sanat ve Beşeri Bilimler Dergisi, 4, ss. 154-181. 


\title{
arts
}

Research Article

\section{Illustrated Genealogy Tradition in the Ottomans: Late 16th Century-Early 17th Century}

\begin{abstract}
Although the lineage of the Ottoman dynasty is included in the early history books, the first silsilenâme in the schematic world history style, belongs to the period of Bayezid II (1481-1512). It is possible to say that this species continues its development until the late periods in the Ottoman Empire with this small and non-pictured work. It is observed that during the reign of Süleyman I (1520-66), when the state was transformed into an empire and its political identity evolved, the interest in this species increased and the genealogies diversified. Historians such as Derviş Mehmed bin Ramazan, Yusuf bin Abdullatif and Şerif Şefii, created genealogies in roll and book format in this period. An extraordinary mobility draws attention in this spieces in the late 16th and early 17th centuries. Unlike the examples prepared at the court in the mid-16th century, these genealogies which contain portrait medallions of the sultans were produced in Baghdad, a province of the Ottoman Empire. The main invention of the Baghdad genealogy producers is that they have adopted a model based on vertical lineage rather than horizontal making a radical change in the page design. In addition, the fact that they each have standard design and fiction as if they were from one hand, makes this manuscript group different. For this reason, these works prepared with certain motivation on the same dates should be considered as a whole. Our focus in this study is to examine these works prepared in Baghdad on the basis of illustrated copies in terms of fiction and design and to reveal the differences between previous examples prepared in the Islamic world.
\end{abstract}

Keywords: ottoman genealogy, genealogic tree, miniature, islamic painting, ottoman manuscripts 


\section{arts}

\section{GíRiş}

Soy bağına dayanan sözlü ve yazılı kültür insanlık tarihinin kadim birikimlerindendir. İslamiyet'in doğduğu coğrafya açısından ele alındığında kuşkusuz güçlü bir asabiyet anlayışı toplumun bütün kurumlarını etkileyen bir vakıaydı. İslamiyet asabiyete dayanan bu sosyolojik bağı, aynı inanca dayanan insanların oluşturduğu bir anlayışa çevirmiş, önceki kimi birikimleri de dönüştürmüştür. İslami ilimlerin tedvin edilmesiyle birlikte önceleri asabiyete dayanan "sözlü ve yazıll soy kültürü" dini ilimlere yardımcı bir rol üstlenmiştir. Siyer ve Hadis gibi ilimlerde soy bağına ait verilere başvurulmuştur (Eren, 2012, s. 167-70; Uğur, 1992, s. 78; Yazıcı, 2015, s. 175, 271). Böylelikle insanlığın bütün dönemlerinde var olan bu kültür İslam tarihi içerisinde de bir gelenek halini almış ve erken dönemden itibaren yazılı hale gelmiştir. Bunun ilk örneği 7.-8. yüzyıllarda bağımsız bir ilim dalı olarak ortaya çıkan Ensab ilmidir. Hz. Muhammed'in ve kabilesini ele alan bu eserleri, 10-11. yüzylllarda seyyid-şerif şecereleri takip etmiştir. Tasavvufun kurumsallaşmasıyla birlikte ortaya çıkan tarikat silsileleri ve hanedan silsileleri bu geleneğin İslam dünyasındaki yazılı alł türlerindendir (Ayğan, 2017, s. 5).

Batı dünyasında Genealogy olarak adlandırılan kavram söz konusu yazılı ve sözlü soy bağına dayanan kültür için kullanılan genel bir ifade olarak karşımıza çıkmaktadır. İslam dünyasında ise silsile, nesep ve şecere kavramları kullanılmıştır. Bunlar arasında silsilenin geleneğin bütün formlarını içermesi ve daha kapsayıcı bir ifade olması nedeniyle geleneğin bu adla isimlendirilmesini bir tercih olarak öngörmekteyiz. Bu tercih, kavram dağınıklığının ortadan kaldırmak ve bu kültürün İslam dünyasında bir gelenek olduğunu göstermek açısından değerlidir.

Silsile geleneği kendi içerisinde farklı gruplara ayrılmaktadır (Tablo 1). Çalışmamızın kapsamını aşacağı düşüncesiyle bütün gruplara değinmeyeceğiz. Bağdat eyaletinde 16. yüzyıl sonları ile 17. yüzyıl başlarında hazırlanan resimli bir grup eser çerçevesinde konuya yaklaşacağız. Bu çerçeveden bakıldığında bu gruptaki eserlerin Orta Çağ İslam dünyasında özellikle Türk-Moğol hanedanları için hazırlanan şematize edilmiş özet dünya tarihi sınıflamasına girdiğini söylemek mümkündür. 


\section{OSMANLILARDA SIILSILENÂME}

Osmanlı döneminde hazırlanan silsilenâmeler, silsile geleneğinin birer alt türüdür. Sözlükte zincir, sıra gibi anlamlara gelen Silsilenâme bir soyun, bir neslin veya bir tarikatın geçmişle olan bağını gösteren vesikalar anlamına gelmektedir (Pakalın, 1983, s. 226-27; Tosun, 2009, s. 206). Osmanlı literatüründeyse, kökü ensâb, şecere gibi ilim kollarına dayanan, ilk insan Âdem peygamberden başlayarak Osmanlı sultanlarına kadar tarihte yaşamıs peygamberleri, sultan ve şahları kendi içerisinde soy ilişkisine göre şematik biçimde sınıflandıran dünya tarihi niteliğinde bir eser türünü ifade ettiği söylenebilir. Tercih ettiğimiz bu tanımlamadan da anlaşılacağı üzere Osmanlılarda gelişen ve adına

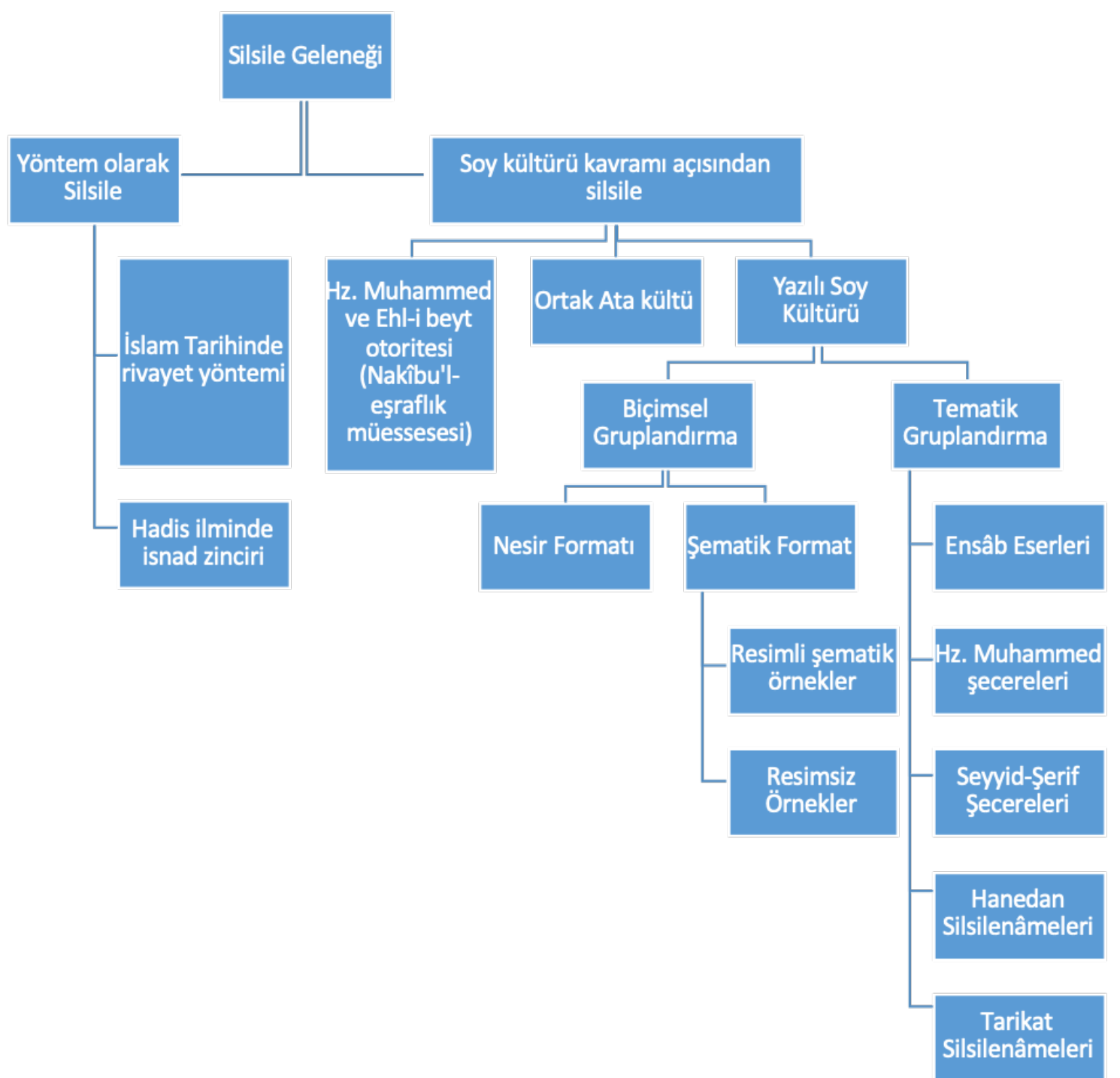

Tablo 1. Silsile geleneğinin sınıfandırıması 


\section{arts}

silsilenâme adı verilen bu türün İslam tarihinde iki önemli dayanağı bulunmaktadır. Bunlardan ilki İslami ilimlerin tedvin edildiği erken dönemlerden itibaren varlığı bilinen Ensâb geleneği; ikincisiyse Orta çağ İslam dünyasında evrensel tarihçilik ile birlikte gelişim gösteren şematik biçimli özet dünya tarihi anlayışıdır. Bu eserlerde hanedanın dünya tarihindeki konumunu vurgulamak amacıyla Âdem peygamberden başlayarak, eserin kendisine atfedildiği son sultana kadar gelinir. İsimler daireler içerisine yazılır, daireler çizgilerle birbirlerine bağlanır.

Silsilenâmeler Osmanlı tarih konulu el yazmaları içerisinde önemli bir grup oluşturur. Ali Emiri'nin (ö. 1924) Yanya'da müfettişlik yaptığı sırada eline geçtiği "Cam-ı Cem Âyin" adlı Silsilenâme bu türün ilk örneklerinden biri olarak gösterilebilir (Ayğan, 2017, s. 11 1; Babinger, 1982, s. 34). Eserin girişinde müellifi Hasan bin Mahmud Bayâtî'nin aktardığı bilgilere göre, 886/1481 yılında çıktığı bir hac yolculuğunda Sultan Cem (ö. 1495) ile tanışmış ve onun ricası üzerine bir Osmanlı silsilenâmesi hazırlamıştır (Bayâtî, 1008, y. 2b-3a).

Silsilenâmeye ilk dikkat çeken Ali Emiri hicri 1331 (1912) ylında eseri neşretmiştir. Ali Emirr̂̀'nin neşrettiği nüsha hakkında kat'i bir bilgimiz bulunmamaktadır. Buna rağmen Câm-ı Cem adlı eserin 1008/1599 tarihli bir nüshasının Millet Kütüphanesi'nde mahfuz olmasından hareketle 1912 tarihli neşrin bu nüshaya dayandığını söylemek mümkündür. Toplam 37 varak olan eser 13 satır düzeninde talik hatla yazılmıştır. Silsiledeki isimler nesih hatla ve kırmızı mürekkeple vurgulanmıştır.

Câm-ı cem adlı silsilenâmenin günümüze ulaşan şematik bir nüshası bulunmamaktadır. Bu yüzden eserin ilk olarak şematik biçimde tasarlanıp tasarlanmadığı, portre içerip içermediği konusunda fikir sahibi değiliz. Serpil Bağcı, l. Ahmed Albümü olarak bilinen eserdeki resimli sayfaların Cam-ı Cem silsilenâmesiyle bir ilgisinin olduğunu ve bu resimlerin tamamlanmamış Cam-ı Cem nüshasına ait olabileceğini ifade etmiştir (Bağcl, 2014, s. 266).

Cem sultan için hazırlanan bu silsilenâmeyle aynı döneme ait başka bir silsile var ki tahtın diğer rakibi II. Bayezid için hazırlanmıştır. Câm-ı Cem'den farklı olarak şematik biçimli olan eser kurgusal açıdan daha yetkin bir görünüm arz etmekteydi. Aynı zamanda Osmanlı saltanatı için hazırlanan şematik biçimli ilk örnek 
olarak kayda geçmişti. Topkapı Saray Müzesi Kütüphanesi'nde H. 1590 numara ile kayıtlı olan eser, Cem Sultan silsilenâmesinden sadece tasarım olarak ayrılmaz. İki eser arasında kurgusal olarak da belirgin farkllıklar bulunmaktadır. Câm-ı Cem silsilenâmesinde Osmanlı soyu Oğuz kimliği çerçevesinde ele alınırken, H. 1590'da ise Osmanlı hanedanı dünya tarihindeki büyük imparatorlukların bir parçası olarak değerlendirilmiştir (Ayğan, 2017, s. 118). Bu yönüyle eser, 13-14. yüzyıllarda TürkMoğol saraylarında sistemleşen hanedan silsilelerinin bir devamı niteliğindedir.

Osmanlılarda şematize edilmiş silsile eserleri zirveyi Kanuni Sultan Süleyman döneminde yakalamıştır. İslam tarihinde silsile türü eserlerin hanedanın kimliğinin belirginleştiği, devletin imparatorluğa dönüştüğü dönemlerde hareketlilik kazandığı göz önüne alındığında bu durum şaşırıcı değildir. Hazırlanmasında politik amaçların ön planda tutulduğu bu eserlerin Osmanlıdaki serüveni de kuşkusuz siyasi tarihle yakından alakalıdır. Fatih Sultan Mehmet (1444-1481) döneminde İstanbul'un fethi, Bizans imparatorluğunun ortadan kaldırıması; Yavuz Sultan Selim (15121520) dönemindeki doğu seferleri ve fetihler Osmanlılara doğu ve batıda eşine az rastlanan bir üstünlük sağlamıştır (Bağcı vd. 2006, s. 34; Uzunçarşlı 2011 , s. 150-51). Bu güçlü politik mirası devralan Kanûnî, Osmanlılara siyasal başarılar kazandırmasının yanı sıra kültürel ivmenin de ana aktörü olmuştur. Başta Yusuf bin Abdullatif (ö. 952) olmak üzere Şerif Şefii ve Derviş Mehmed bin Ramazan gibi tarihçiler Subhatü'l-ahbâr olarak bilinen ortak bir isimle silsileler üretmişlerdir. Bunlar arasında Derviş Mehmed bin Ramazan ile Şerif Şefii' nin hazıladığı hanedan silsileleri rulo olarak tasarlanmıştır. Yusuf bin Abdullatif'in Subhatül'l-ahbar'ı ise kitap biçiminde tasarlanmıştır. Bu eser Osmanlı saray çevresinde kabul görmüş olacak ki uzun bir dönem çoğaltılımışır.' Baştan sona bir sıra halinde saltanat üyelerini tanıtan bu silsilenâmeler Osmanlıların sınırlarının uzandığı tüm bölgelerde meşruiyetinin sağlamlaştııımasında kuşkusuz önemli rol oynamıştır.

16. yüzyılda silsilenâme tasarlanmasında yakalanan başarı Tomâr-ı Hümâyûn adı verilen büyük bir eserin hazırlanmasına öncülük etmiştir. Topkapı Saray Müzesi Kütüphanesi'nde A. 3599 numarayla kayıtı bu silsile yalnızca Osmanlıların değil, İslam tarihinin en büyük silsile projesidir. Yusuf b. Abdullatif, Şerif Şefii ve Derviş Mehmed 1 Geç dönem örneklerinden biri Topkapı Saray Müzesi Kütüphanesi'nde kayıtıdır (TSMK B. 193). Eserde her hanedan farkı renk daire ile temsil edilmiştir. Dairelerin kenarlarındaki kimi metinler servi formunda yazılmıştır. Bkz. Yusuf b. Abdüllatif, 1176, y. 5b-6a. 


\section{$\operatorname{arts}=$}

bin Ramazan'ın hazırlamış olduğu eserler belirli politik hedeflerle hazırlanan küçük boyutlu, sade tasarımlı eserlerdi. Osmanlıların yükselme döneminde gerçekleştirdiği fetihler sonucunda saraya İslam dünyasının muazzam eserleri girmiş ve kuşku yok ki bu eserlerin örnekliği ile tarihçilik anlayışında değişimler meydana gelmiştir. Saraya giren eserler arasında İlhanlı döneminde Reşidüddin Fazlullah (ö. 1318) tarafından hazırlanan ve Câmiü't-tevârih'in bir bölümü sayılan Şuab-ı Pençgana silsile geleneği açısında nadide bir değere sahiptir. Kendi dönemine kadar kurgu ve tasarım açısından İslam tarihinin en kapsamlı silsilesi olan bu eser Topkapı Sarayı'nda bulunmaktaydı. İlhanlı sarayı için hazırlanmış bu silsilenin Osmanlı tarihçilerinin bakış açısını zenginleştirdiği ve daha iyisini yapma hususunda motive ettiği düşünülebilir.

Osmanlı sarayına girmiş olan nitelikli silsile eserlerin varlığı ve 16. yüzyılda silsilenâme tasarlanmasında yakalanan başarı Tomâr-ı Hümâyûn adı verilen büyük bir eserin hazılanmasına zemin hazırlamış olmalıdır. Topkapı Saray Müzesi Kütüphanesi'nde A. 3599 numarayla kayıtı bu silsile² yalnızca Osmanlıların değil, İslam tarihinin en büyük silsile projesidir. Eserin devasa ölçüleri, daire içi yazıların ve tezyinatın niteliği, özenle uygulanan renk kodlaması (her hanedan için farklı renkler tercih edilmesi) gibi hususlar, İslam dünyasında hazırlanmış örnekleri aşan kusursuz bir şecere üretme amacını ortaya koymaktadır (Resim 1).

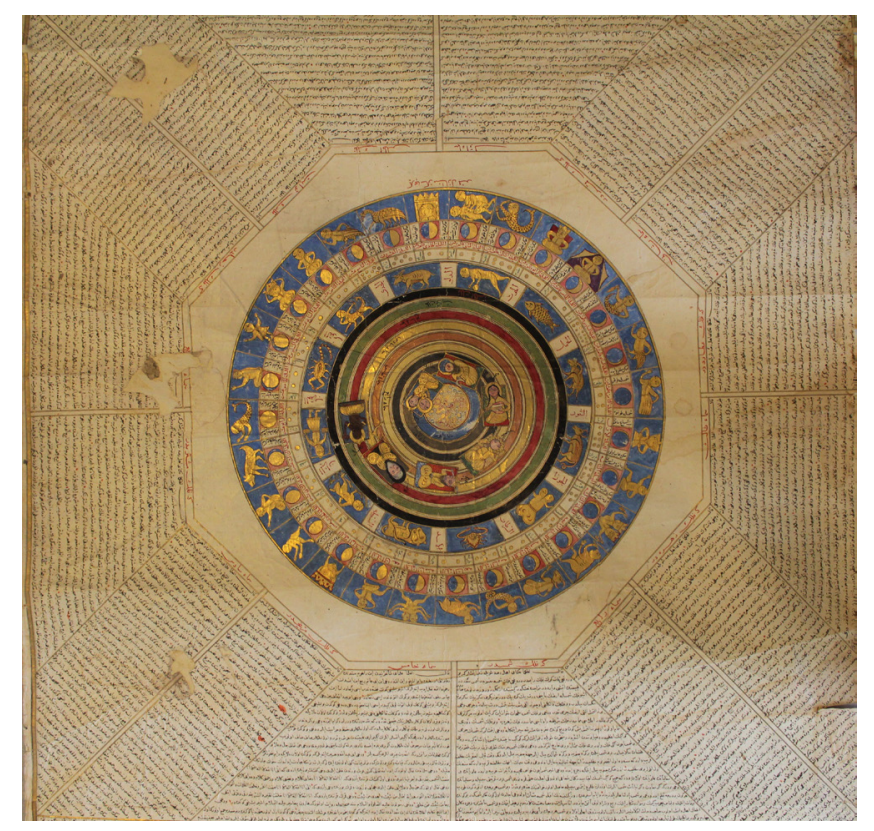

Görsel 1. Sûretu seb'u semavât (Yedi gök tasviri), Tomar-ı Humâyûn, 16. yüzyıl, TSMK A. 3599, (Aygan, 2017, s. 146)

$\overline{2 \text { Eser, } 3116 \times 79 \text { cm }}$ ölçülerindedir. Sülüs ve nesih hatla yazılmışıı. Bkz. Karatay, 1961, s. 241. 


\section{GELENEĞiN EVRiMi: 16. YüZIL SONU ILE 17. YüZYIL BAŞLARINDA SILSILENÂMELER}

Derviş Mehmed bin Ramazan ve Şerif Şefii'nin rulo olarak hazırladığı, Yusuf bin Abdüllatif'in kitap şekline getirdiği Sübhatü'l-ahbâr isimli silsilenâmeler; Seyyid Lokman'ın yazdığı, Nakkaş Osman'ın betimlediği Zübdetü't-tevârihler ve nihayet hanedanın en büyük şeceresi sayılan Tomar-ı Hümâyûn adlı eser 16. yüzylın Osmanlılarda silsile geleneği açısından zengin bir dönem olduğunu gösterir.

16. yüzylın sonlarına gelindiğinde Osmanlının Bağdat eyaletinde bu tür yeni bir formla görünmüştür. Kitap formatında küçük boyutlu hazırlanan eserler şematik biçimli tasarlanmış, daireler içerisine portreler de çizilmiştir. Önemle vurgulamak istediğimiz husus Bağdat silsilenâmelerinde yeni olanın tek başına ne şematize form ne de portre içermiş olmasıdır. Zira II. Bayezid dönemine atfedilen örnek küçük boyutlu şematik hanedan silsilenâmelerinin varlığını göstermekteydi. Benzer biçimde daha önce sarayda hazıllanmış Zübdetü't-tevarih eseri de resmin metin-şecere ile birlikte sunulduğunu gösteren örnekti. Bu yüzden Bağdat silsilenâmelerini farklı kllan husus bütünüyle şematik olarak tasarlanmış bir eser türünün Osmanlılardaki ilk resimlenmiş örnekleri olmasıdır.

Silsile geleneğinde yaşanan bu gelişmeyle alakalı tartışılan mevzulardan biri de resimli silsilenâmelerin saray dışında neden bir eyalette ortaya çıkığıdır. Kuşkusuz burada Bağdat'ın jeopolitik konumu üzerinde durulması gerekmektedir. Çalışmanın sınııını aşmadan bu konuya kısaca değinmek yerinde olacaktır.

Bağdat, tarih boyunca İslam dünyasının en önemli siyasi ve kültürel merkezlerden biri olmuştur. Abbasilere başkentlik yapmış, çeviri faaliyetlerinin yapıldığı Beytü'l-hikme burada kurulmuştur. Büyük Sünni alimlerinden Ebu Hanife, meşhur mutasavviflardan Abdulkadir Geylani'nin türbeleri ile on iki imamın bir bölümünün kabirleri de Bağdat'tadır. Bu yönüyle yalnızca Sünniler için değil, Şii dünyasının da önemli merkezlerinden biridir. Zira Şii öğretiyi devletin temeline alan Safeviler 1509 yllında Bağdat'ı kendi idaresine almış, bu tarihten itibaren bölge Osmanlı-Safevi arasında güç savaşının odağı haline gelmiştir. Nihayet 1555 yılında Amasya Antlaşması ile Bağdat'ta Osmanlı egemenliği tanınmıştır (Gülcü, 1999, s. 2526; Halaçoğlu, 1991, s. 433). 


\section{arts}

Osmanlılar kazanmış oldukları siyasi başarıları kültürel etkinliklerle kalıcı hale getirme çabası içerisinde olmuşlardır. 16. yüzyıl ortalarından itibaren şehrin imarına yönelik çalışmalar yapılmış, bu kapsamda Abdulkadir Geylânî'nin (ö. 1165-66) cami ve türbesi için vakıflar kurulmuş, İmâm-ı Âzâm Ebu Hanife'nin (ö. 767) mezarını tespit edip türbe ve medrese inşa edilmiştir (Emecen, 1989, s. 332; Halaçoğlu, 1991, s. 433). Bunun yanı sıra kitap kültüründe de gelişmeler olmuş, ünlü devlet adamı Sokullu Mehmet Paşa'nın oğlu Hasan Paşa'nın (ö. 1602) valilik yaptığı dönemde resimli kitaplar hazırlanmıştır. Bunlar arasında silsilenâmeler önemli bir grup oluşturmaktadır. Silsilenâmelerin ketebe kayıtlarındaki h. 1006 tarihi de Hasan Paşa'nın 1598-1602 yılları arasında Bağdat'ta valilik yaptığı döneme denk gelmektedir. Koleksiyoner bir sanatsever olarak tanınan Hasan Paşa'nın zengin bir hazinesinin olduğu da bilinmektedir (Bağcl, 2000, s. 198; Milstein, 1990, s. 2). Dolayısıyla Hasan Paşa gibi güçlü ve zengin bir devlet adamının hamiliğini yaptığı bu eserlerin Osmanlı saltanatının dünya hükümranlığına dayanan ideolojisini eyaletlere yaymada önemli bir işlev gördüğü düşünülebilir (Bağcl, 2000, s. 198).

\section{Sayfa Tasarımları}

Bağdat silsilenâmelerine gelinceye kadar Osmanlılarda erken örnek dahil olmak üzere hazırlanmış olan kitap silsilenâmeler yatay formatta hazırlanmıştı. Türün kökenleri düşünüldüğünde bir soyun kesintisiz biçimde devam ettiğini göstermek açısından doğal bir tasarım modeliydi. Bağdat silsilenâmelerinde bu formatın dışına çıkılmış, sayfalar dikey olarak tasarlanmıştır. Bu farklılık salt sanatçıların tasarımıyla açıklanabilir bir durum değil, silsiledeki soyların tarihsel akışının sunum biçimindeki (kurgu) değişiklikle alakalıdır. Zira silsilelerin giriş bölümünde yer alan 7-8 sayfalık giriş metninde devletler tarihi, tabaka adı verilen bölümlere ayrılmış ve her bölüm içerisinde farklı hanedanlar ele alınmıştır. Şematik bölüme geçildiğinde ise giriş bölümünde sınıflandırılan hanedanlar, iki veya üç hanedan bir sayfada ele alınmak üzere sistemli biçimde yerleştirilmiştir. Her yeni hanedan sayfanın üst kısmından tanıtıcı bir metinle başlamaktadır. Bu metin de şematik bölüme uyum sağlayacak biçimde geometrik bir biçimle sınılandırımıştır (Zübdetü tarîh, 1597a, y. 24b-26a).

Sayfalar dikey olarak kurgulandığı için bir Bağdat silsilenâmesinde hangi hanedanın hangi sayfada olacağı belirlidir. Bu sebeple resimli ve resimsiz bütün 
nüshalar aynı sayfa sayısıyla hazırlanmıştır. Sekiz sayfa giriş metni, yirmi iki sayfa da şematik bölümden oluşan standart bir içeriğe sahiptir (Resim 2).

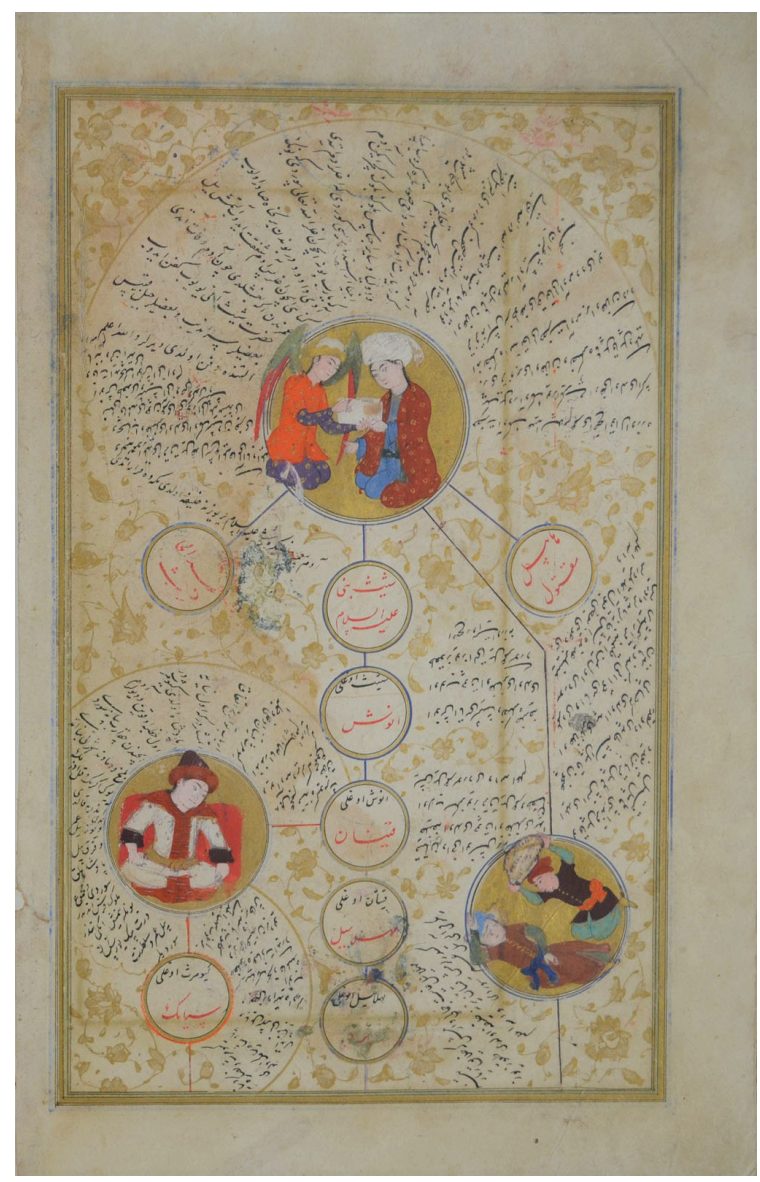

Görsel 2. Silsile bölümü giriş sayfası, Zübdetü târih, TSMK H. 1654, y. 5b (Aygan, 2007, s. 348)

Şematik bölüm Hz. Âdem'den başlayan ve kollara ayrılan soy dizilerinden oluşmaktadır. Soy dizileri her sayfanın üst kısmından başlar, aşağıya doğru çizgilerle ilerler, çizgi üzerindeki daireler içerisine soya mensup kimselerin isimleri yazılır. Kalan boşluklara ise isimlerle ilgili kısa tanıtıcı bilgiler verilir. Soyun sonraki sayfalarda devam edildiği durumlarda, her sayfanın başına içinde hangi soyun devam edildiği belirten bilgilendirici daire veya yarım daire yerleştirilir. Örneğin Moğol soyunu içeren Cengizhaniyân tabakası üç sayfada devam eder. Her bir sayfanın başına yerleştirilen kartuşların içerisine "Bu daireler Cengizhan evladün ve ensâbün beyân ider." (Zübdetü târih, 1600, y. 26b) yazılmıştır. Böylelikle ayrı sayfalarda birbirinin devamı olan soy dizileri arasında bağlantı sağlanmış olur.

Bağdat silsilenâmelerinde sayfa tasarımını belirleyen üç temel öğe bulunmaktadır. Bunlar, daireler, daireleri birbirine bağlayan çizgiler ve tanıtıcı kenar 


\section{$\operatorname{arts}=$}

yazılarıdır. Silsilenâmelerde bu üç unsur rasgele değil, belirli bir program içerisinde sayfaya yerleştirilmiştir. Hz. Âdem peygamberden başlamak üzere ilerleyen ve kollara ayrılan soy dizileri kronolojik biçimde sınıfandııımış ve her hanedan yeni bir sayfada ele alınmıştır. Başından sonuna kadar düzenli olarak ilerleyen silsilenâmelerde on iki imam dizisinin ele alındığı sayfa en görkemli sayfadır. Burada yer alan bütün daireler simetrik olarak yerleştirilmiştir. Sayfanın üst ortasına büyükçe Hz. Ali'nin isminin yazııı olduğu daire, sayfanın alt kısmına aynı hizada ve yine büyükçe İmam Ali ibn Musa (ö. 818) isminin yazlı olduğu daire yerleştirilmiştir. Diğer on imam beşerli olarak sayfanın sağında ve solunda yer almıştır. Sayfadaki bütün daireler, çizgiler ve kenar bilgileri özenle tasarlanmış bir kompozisyonu tamamlayan unsurlar gibi ele alınmıştır. Kitap sanatları açısından on iki imam sayfasının en iyi tasarlandığı nüshalardan biri Ankara Ełnografya Müzesi'nde AEM 8457 numarayla kayıtlı resimli silsilenâmedir. 25 x 14.5 boyutlarındaki resimli silsilenâme 18 yapraktan oluşmaktadır. Eserde toplam 146 madalyon portre bulunmaktadır. Eserin dili Farsça'dır. 17. yüzyıl başlarında Bağdat'ta Şii bir müşteri için hazırlandığı düşünülen eserin bu sayfasında daireler içerisine on iki imamın portreleri yapılmıştır. ỉkişerli olarak dairelerde yer alan figürler, başlarında hale, yüzleri peçeli ve yeşil sarıklı olarak gösterilmiştir (Resim 3).

Osmanlı hanedanına gelinceye kadar silsilenâmenin her bir sayfasında iki veya üç soy dizisi birlikte ele alınmıştır. Osmanlı hanedanına geçildiğindeyse aynı dönemde hüküm süren saltanatlara yer verilmemiştir. Silsilenin bu kısmında dairelerin boyutları büyütülmüş ve sultanların isimlerinin yazıldığı (veya portrelerinin çizildiği) bu daireler sayfanın tam ortasına konumlandırılmıştır. Çevrelerinde ise şehzade isimlerinin yazlı olduğu küçük daireler ile bu dairelerin aralarına söz konusu sultana ait bilgiler verilmiştir. Merkezdeki sultan dairesi, küçük şehzade daireleri ile sultan hakkındaki bilgiler sayfa içerisinde dairesel bir kompozisyonda ele alınarak esere görsellik kazandırımıştır. (Resim 4)

Bağdat silsilenâmelerinde tasarım açısından dikkat çeken özelliklerinden biri de renk kodlaması içermemesidir. Oysa ki geç orta çağdan bu yana i̇slam dünyasında 


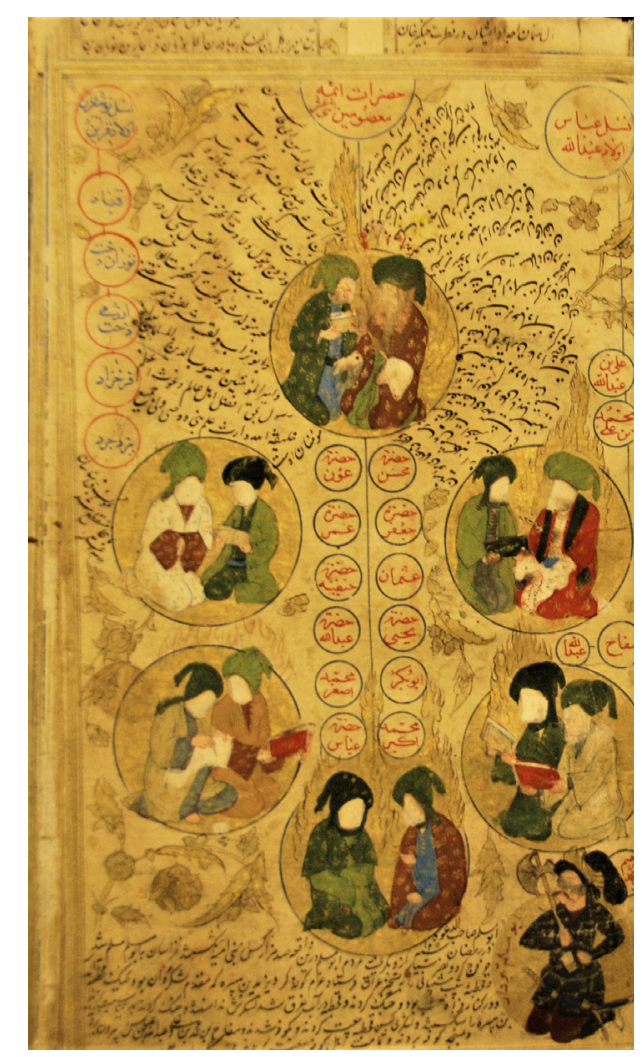

Görsel 3. On iki imam sayfası, Cem-i târih, AEM nr. 8457, y. 8 a (Aygan, 2017, s. 218)

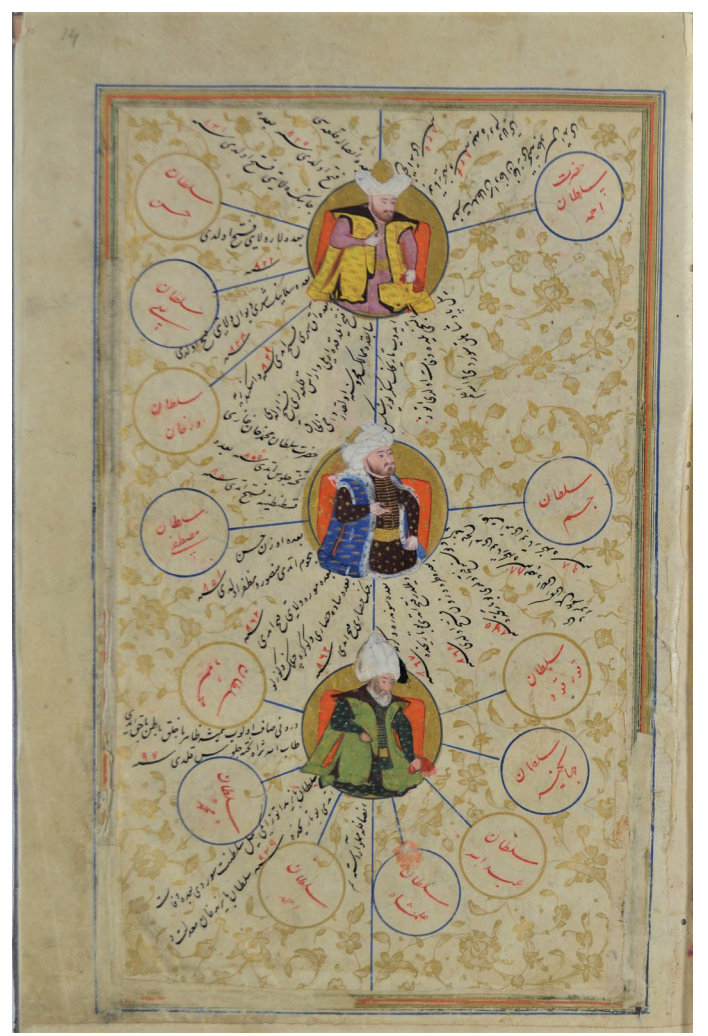

Görsel 4. Osmâniyân, Zübdetü târih, TSMK, A. $3110,14 a$ (Aygan, 2017, s. 586) 


\section{arts}

hazırlanan şematik silsilenâmelerde her hanedanın farklı bir renkle temsil edilmesi bir gelenek haline gelmişti (Binbaş, 2011, s. 502). Bu eserlerde aynı soy dizisinde yer alan dairelerin içleri aynı renkle boyanmış ve diğer soy dizilerinden ayrımıştır. Bu durum silsile türü eserlere görsel açısından değer kazandırdığı gibi daha anlaşılır olmasını da sağlamıştır. Peki Bağdat silsilenâmelerinde geleneğin en temel araçlarından birinin tercih edilmemesinin ne gibi sebebi olmalıdır? Bu sorunun cevabı Bağdat silsilenâmelerinin gelenek içerisindeki özel konumunu perçinleyecektir. Bize göre bu durum iki faktörle açıklanabilir. Bunlardan ilki daha önce de ifade ettiğimiz gibi Bağdat silsilenâmelerinin her biri müstakil biçimde tasarlanmış dikey sayfalardan oluşmasıyla alakalı olmalıdır. Çünkü bu özellik silsile dizilerinin anlaşılır olmasını sağladığından renk kodlamasına intiyaç duyulmamıştır. İkinci faktör ise Bağdat silsilenâmelerinin temelde resimli bir proje olarak başlamış olmasıdır. Her ne kadar resimsiz kopyalar varsa da 16. yüzyıl sonunda Şemailname ve Zübdetü't-tevârih örnekleriyle kitap resimlemede yakalanan ivmenin bu türe sağladığı katkılar göz önüne alındığında bu varsayımın güçlü olduğu ortaya çıkacaktır. Gerek hükümdarlar gerek dini karakterler veya kahramanlar Nakkaş Osman'ın daha önce uyguladığı ikonografik program dahilinde madalyon portre olarak silsile dizilerinde yer almıştır. Kuşkusuz silsile türü eserde dairelerin içerisine isim yazmak ve renklendirmek gibi unsurlardan hiçbiri bir karakterin portresini yapmak kadar güçlü bir etki bırakmayacaktır. Iş̧te bu sebeple Bağdatı sanatçılar, Osmanlı portre modellerinden ilham alarak hazırladıkları resimli silsilenâmelerde, renk kodlamasına gerek duymamışlar ve seri üretim tarzında hazırlanan bu kopyaların resimsiz nüshalarında bile bu anlayışı değiştirmemişlerdir.

\section{Kurgu}

Bağdał silsilenâmeleri özgün sayfa tasarımının yanı sıra yeni bir kurguyla ortaya çıkmıştır. İki bölümden oluşan eserin bazı nüshalarının başına Hz. Muhammed şeceresi ilave edilmiştir (Aygan, 2017, s. 100). 26 sayfadan oluşan şecerenin ardından asıl birinci bölüm 7-8 sayfalık bir girişle başlar. Bu giriş iki temel bahis içermektedir. İlkinde sırasıyla Allah'a şükür, kâinatın ve insanoğlunun yaratılışı, Hz. Muhammed'in peygamber olarak seçilişi ve Kanuni Sultan Süleyman'a övgüler yer almaktadır. Bu bahsin sonunda eserin isminin Zübde-i Târih olduğu bir nazım içerisinde belirtilmiştir. İkinci bahiste Âdem peygamberden Hz. Muhammed'e kadar gönderilen 
peygamberler arasındaki zaman dilimi tartışılmışıı. Bu konudan sonra tartışılan bir diğer husus da Ashâb-ı kehf kıssasıdır. Bu tartışmaların ardından gayb konusu ele alınmış ve Allah'tan başka kimsenin bilemeyeceği beş gaybî konu sıralanmıştır. Bu anlatımların ardından silsilenâmeyle alakalı sınıfandırmaya geçilmiştir. Dünya tarihi cahilî ve İslamî olarak iki ana döneme; cahilî dönem kendi içerisinde Pişdâdiyân, Kiysâniyân, Eşkâniyân ve Sâsâniyân olmak üzere tabaka adı verilen dört bölüme ayrımıştır. İslami tabakalar ise Ben-i Ümeyye, Abbâsiyân, Sâmâniyân, Âl-i Büveyh, Ben-i Sebüktegin, Harezmiyân, Melâhide, Selçûkiyân, Cengiziyân ve Âl-i Osmân olmak üzere on gruba (tabaka) ayrımıştır.

Giriş metninin yanı sıra eserin şematik bölümü içerisinde iki tür yazılı alan bulunmaktadır. Bunlar daire kenarlarındaki yazılar ile her tabakanın başında yer alan metinlerdir. Osmanlı hanedanına geçildiğinde bu metin karşılıklı iki sayfa olacak şekilde geniş tutulmuştur. Daire arasındaki yazılar silsilenin peygamberler ve kadim İran hükümdarlarının yer aldığı ilk bölümlerde yoğunlaşmaktadır. Bu bilgilerde dini karakterin kutsal kitaplarda geçen kıssasına, hükümdarların da tarihte şöhre† bulduğu farklı yönlerine değinilir. Kenar bilgileriyle ilgili olarak iki örnek vermeyi uygun bulmaktayız. Silsilenâme nüshalarında aynı daire içerisinde betimlenen Hızır-ilyas peygamber dairesinin kenarında şu bilgiler yazılmıştı;;

Hazret-i Hızır ve Hazret-i ilyâs birisi deryâda ve birisi yabânda müvekkeldir. Ve her Ramazanda Kudüs-i Şerifte olurlar. Ve her yıl hac zamânında hac edip âb-ı zemzemde buluşurlar (Zübdetü târih, 1597b, y. 21 a).

Efrâsiyâb ile ilgili olarak ise şu bilgilere yer verilmiştir;

Bu Efrâsiyâb melik-i Türk idi. Mecmû-u Türkistân ve Meşrik halkı ve Mâverâünnehir bunun elinde idi. Ve bi-hesab askeri vardı şöyle ki adedin bilmezdi. Lesker çıkıp Menuçehr üzerine geldi. Ve yedi yıl Menuçehr'i hesar etti. Âhir sulh ettiler. Bir pehlivanı vardı adı Erş idi. Demâvend dağı üzerine çıkıp bir ok attı. Ol attığı ok bir gergesin kanadına dokunup ol iklime gerges uçup Demâvend ve Tâberistân'ı geçip Tâcihun kenarına düştü. Ol diyârı cümle Efrâsiyâb zabt etti. Vallâhu 'alem (Zübdetü't-târîh, 1598, y. 19b).

Tabaka adı verilen hânedanların başındaki kısa metinlerde ise bahsi edilen saltanat içerisinde kaç hükümdarın tahta geçtiği, hanedanın kaç yıl hüküm sürdüğü, hangi tarihte ve kim tarafından kurulduğu gibi özet bir anlatım yer almaktadır. Örneğin Harezmiyân tabakasının başında yer alan metinde şu bilgilere yer verilmiştir: 


\section{$\operatorname{arts}=$}

Tabakâ-yı Harezmiyân. Bunlar dokuz tendür. Bunlar 172 yıl 5 ay beglik sürdüler. Bilge Tegin ve Nûş Tegin Ferruh oğlanları idi. Ve bu ol Sultan Sencer havâslarından bir beg idi. Sultan Sencer buna Harezm begligin verdi. Vakta ki Bilge tigin vefat etti, onun büyük oğlu Kutbettin idi. Sultan Sencer Harezm'i Kutbettin'e verdi. İs bu tarihte: 491. (Zübdetü târîh,1597b, y. 23a).

Daha önce de ifade edildiği gibi şematik bölümdeki Osmanlı hanedanına ait bilgiler karşııklı iki sayfa olarak düzenlenmiştir. Metnin başında Osmanlıların atalarının Nuh Peygamberden beri hükümdar olduğu ve hâkim oldukları yerleri adâletle yönettikleri, bu sebeple saltanata lâyık oldukları vurgulanmıştır. Daha sonra Osman Bey'in atalarının Türkistan bölgesinden çıkıp Azerbaycan, Horasan ve Irak bölgelerine geldiği, yüz yetmiş yıl Ahlat bölgesinde durduktan sonra Moğol istilasıyla birlikte Anadolu'nun iç kısımlarına göç ettikleri anlatılmıştır. Bundan sonra metinde Ertuğrul Bey'in Anadolu Selçuklu yönetimi ile olan olumlu ilişkilerinden söz edilmiştir. Moğollarla olan çarpışmalarda Ertuğrul Gazi ve ahâlisinin başarıları sayesinde Selçuklu Devleti nezdinde itibar kazandıkları ve hükümdar Alaaddin bin Keykubad'ın kendisine önce Ankara civarını, sonra da Söğüt, Domaniç bölgelerini verdiği ifade edilmiştir. Metindeki anlatımdan Osmanlıların Selçuklu hanedanıyla olan yakın ilişkisinin Osman Bey döneminde de devam ettiğini anlıyoruz. Dönemin Selçuklu Sultanı Alaaddin bin Feramürz'ün Moğollarla olan çarpışmalarında Osman Bey'i görevlendirdiği ve nihayetinde ona sancak verdiği anlatılmıştır. Metnin son bölümünde Anadolu'da Selçuklu hakimiyetinin sona erdiği ve saltanata layık olduklarından dolayı birçok memleketin Osmanlıların eline geçtiği ifade edilmiştir. (Zübdetü târîh, 1597a, y. 27b-28a)

İki sayfalık başlangıç metninin ardından Osmanlı sultanlarının dizisi şematik olarak Osman Gazi' den başlamak üzere III. Mehmed'e kadar devam eder. Silsilenin bu kısmında sultanlara ait cülus tarihleri, fetihleri ve vefat tarihleri dairenin çevresine sırayla yazılmıştır (Bkz. Resim 4).

Bağdat Silsilenâmelerinde yukarıda bahsettiğimiz ve bütün nüshalarda standart olarak var olan metinlerin kaynağı hakkında kesin bir kanıya sahip değiliz. Giriş bölümünde eserin kimin yazdığı hakkında bir bilgi verilmemektedir. Osmanlı silsile geleneği içerisinde kurgu ve tasarım olarak önceki örneklere benzememektedir. Bu da başta özgün bir metin olduğunu akla getirmektedir. Fakat girişteki metinde dönemin sultanı III. Mehmed'e değil de Kânuni Sultan Süleyman'a övgü içermesi 
karışıklığa yol açmaktadır. Bir problem de eserin isminin yine giriş metninde Zübde-i târih olarak adlandırımasıdır. Bu isim bize III. Murat dönemi resimli tarih kitabı ve aynı zamanda bir silsile olan Zübdetü'-tevârih'i hatırlatmaktadır.

Silsilede son hükümdarın III. Mehmed olması ve etrafında verilen bilgilerde vefa† tarihi yerine Halledallâhu Teâlâ mülkehu (Yüce Allah mülkünü daim eylesin) ifadesinin yer alması eserin III. Mehmed'in saltanat döneminde hazılandığını göstermektedir. Bunun yanı sıra Hz. Muhammed'in şeceresinin bulunduğu nüshalarda eserin ketebe kayıtlarında tarih verilmektedir. Örneğin Topkapı Saray Müzesi kütüphanesinde kayıtlı H. 1324 numaralı resimli nüshanın ketebe kaydında şu bilgiler yer alır:

Kâtibuhu Yusuf b.Muhammed ed-Dizfôî Sakin-i Bağdâd ğafarallâhu teâlâ li'kâtibihi ve li sâhibihi veli'men karae fîhi tahriren fî târihi şehr-i Rebîulevvel sene sitte ve elf mine'l-hicreti'nnebeviyyeti (Zübdetü târîh, 1597a, y. 14a).

(Bunun yazanı Bağdat sakini Yusuf b. Muhammed Dizfûlî' dir. Allah yazanının, sahibinin ve okuyucusunun günahlarını bağışlasın. Rebiulevvel ayında, peygamberin hicretinin bin altı (Ekim-Kasım 1597) yılında yazıldı.) Şecere ilaveli kopyaların ketebe kaydında verilen bu bilgiler eserin kuşkusuz biçimde III. Mehmed döneminde ve Bağdat'ta hazırlandığını doğrulamaktadır.

\section{Minyatürlerin Üslup ve İkonografyası}

Bu çalışmaya konu olan Bağdat silsilenâmelerinin çoğunluğu resimli nüshalardan oluşmaktadır. ${ }^{3}$ 16. yüzyıl sonlarında başlayan, 17. yüzyılın ilk çeyreğine kadar izlerine rastlanan resimli silsilenâmeleri incelerken üç temel meseleye özetle değinmek yerinde olacaktır.

Öncelikli olarak ortaya konulması gereken husus bu serinin, Osmanlıların 16. yüzyıl içerisinde silsile ve resimli kitap geleneğinde yakaladığı ivmeyle yakından

3 Tespit edilen resimli nüshalardan dördü Topkapı Saray Müzesi Kütüphanesi'nde H. 1324, H. 1591, H. 1624 ve A. 3110 numaralarla kayıtıdır. Diğer nüshalar ise şunlardır: Dublin, Chester Beatty Library, CBL T.423; Karlsruhe, Badische Landesmuseum, Hs. Rastatt 201, Los Angeles County Museum of Art M.85.237.38.; Kahire Milli Kütüphanesi, Tarih Türkî Halil Ağa 30; Londra, Nasser Khalili koleksiyonu, MS 581; Kuveyt Ulusal Müzesi, LNS 66 MS. İstanbul Üniversitesi Kütüphanesi'nde T. 6092 numarayla kayıtı silsilenin 17 yaprağı Bağdat okuluna aittir. Günümüze eksik ulaşan eserlerden biri de 17. yüzyıl başlarına tarihlendirilen Stuttgart, Linden Museum Inv. Nr. VI. A1 155 nüshasıdır. 17. yüzyıl başına tarihlendirilen bir diğer eser (Paris Bibliothec National Supp. Turc. 126) renklendirilmemiş portreler içermektedir. Ankara Etnografya Müzesi'nde no. 8457 silsilenâme ise ikonografik yaklaşımı ve üslubuyla diğer kopyalardan ayrımaktadır. Eserin serlevha tezhibi Safevî üslubuna işaret ederken, kurgu ve ikonografya Şii yanlısı Safevi bir müşteri için hazırlanmış olduğunu düşündürmektedir. 


\section{arts}

alakalı olduğudur. Osmanlı dizisinde Nakkaş Osman'ın Şemailnâme ve Zübdetü'ttevârih eserlerindeki portrelerinin model olarak alınması bu ilişkiyi açıkça ortaya koymaktadır. İkinci önemli nokła hâmilerin rolüdür. Saray dışında hazırlanan eserlerin büyük ölçüde valiler veya tarikatların gözetiminde hazırlandığı bilinmektedir. ${ }^{4}$ Silsilenâmeler açısından bakıldığında Nakkaş Osman'ın kalıplarının Bağdat'a taşınarak farklı bir türde yeniden canlandırıması bilinçli bir motivasyonla hareket eden bir hâminin varlığına işaret etmektedir. Bu hâmi de kuşkusuz Hasan Paşa' dır. Osmanlı devlet idaresinde etkin olan Sokullu ailesinin bir ferdi olan Hasan Paşa'nın Bağdat'ta valilik yaptığı 1598-1603 tarihleri arasında birçok eserin hazırlanmasında öncülük yaptığı bilinmektedir (Bağcı, 2000, s. 197-98; Değirmenci, 2017, s. 189; Milstein, 1990, s. 2). Bu tarihler aynı zamanda ilk silsilenâmelerin de hazıllandığı tarihlerdir. Dolayısıyla bu eserlerin Hasan Paşa gözetiminde hazırlanmış olması muhtemeldir. Bunu doğrulayan somut araştırmalar bulunmaktadır. Bu çalışmalarda Karlsruhe silsilenâmesinin 16b yaprağında elinde şahin olan bir şehzade tasvirinin aynı yıllarda Hasan Paşa'nın emriyle hazılanmış Câmiü's-siyer adlı yazmanın bir minyatürüyle benzerlik gösterdiğine dikkat çekilmiştir (Bağcı, 2000, s. 197; Değirmenci, 2017, s. 190). Üçüncü mesele ise Bağdat'ta gelişen minyatür sanatının üslup ve ikonografyasıdır. Değişen siyasi iktidarlar, sanatçı hareketliliği ve Bağdat'ın çok kültürlü yapısı, karakterize bir üslubu ortaya çıkarmış görünmektedir. Kendine has bir karakter gösterdiği için Bağdat üslubu veya eyalet üslubu olarak adlandırılmaktadır. Bu üslup, Osmanlı sarayında hazırlanan el yazması eserlerin minyatürlerindeki resmi havadan farklı olarak hareketli kompozisyonlar, canlı yüz ifadeleri ve sayfa kenarlarına taşan tasvirlerle kendini belli eder.

Bağdat'ın hareketli sosyolojisinin, canlı tasvirlerle ifade bulduğu el yazması üretimlerinin 16. yüzyıl sonlarına doğru ivme kazandığı görülmektedir. Bu dönemde hazırlanan resimli el yazmalarını genel itibariyle üç gruba ayırmak mümkündür. Birinci grup Mevlevîlere ait sûfî menkıbe ve biyografi türü eserlerdir. İkinci grup Hz. Ali, ehl-i beył ve Şii trajedisini konu alan eserlerdir. Üçüncü grup ise Silsilenâmelerdir. Bu çalışmada bizi ilgilendiren husus Silsilenâmelerdir (Milstein, 1990, s. 4).

Bağdat silsilenâmelerindeki portreler içleri altınla bezenmiş 3-4 cm arasında

4 Saray dışında hazıılanan eserler için bkz. Tanındı, 2001, s. 505-30, Kahire, Sam ve Halep'teki yerel yöneticilerin hamiliği için bkz, Bağcı vd. 2006, s. 243-45; Mahir, 2005, s. 66-68; Bağdat'taki yerel yöneticilerin kitap sanatı faaliyetleri için bkz. Bağ cı vd. 2006, s. 246-47; Mahir, 2005, s. 67-68; Milstein, 1990, s. 4; Sufilerin kitap sanatındaki rolü için bkz. Çağman, 1979, s. 651-77; Çağman ve Tanındı, 2005, s. 505-30. 
değişen çaplardaki daireler içerisinde yer almaktadır. Osmanlı dizisindeki portreler standart biçimde $4 \mathrm{~cm}$ çapındadır (Bkz. Resim 4). Portre ve tasvirlerin çoğunlukla daire dışına taşması, figürlerin baş-gövde uyumlarında dengesizlik bulunması gibi ortak hususiyetler Bağdat üslubunun bir yansıması olarak kabul edilebilir. Ortak özelliklerinin yanı sıra resimli silsilenâme nüshaları arasında farkllıkların bulunduğunu söylemek mümkündür.

Örneğin Topkapı Saray Müzesi Kütüphanesi'nde bulunan 1006 tarihli bir silsilenâmenin (TSMK H. 1591) minyatürleri bariz biçimde farkllık göstermektedir. Renklerin kullanımı, portrelerdeki dış kontuarların çizimi ve figürlerin baş-gövde uyumları, bu eserde acemi bir sanatçının çalıştığını göstermektedir (Resim 5). Aynı hattat tarafından aynı yılda hazırlanan ve bütün özellikleriyle aynı atölyeden çıktığı anlaşılan başka bir kopyanın (TSMK H. 1324) minyatürlerinin ise usta bir ressam elinden çıktığını göstermektedir. Bu durum iş yoğunluğundan dolayı kimi eserlerde usta sanatçıların öğrencilerini çalıştırdıklarını düşündürmektedir.

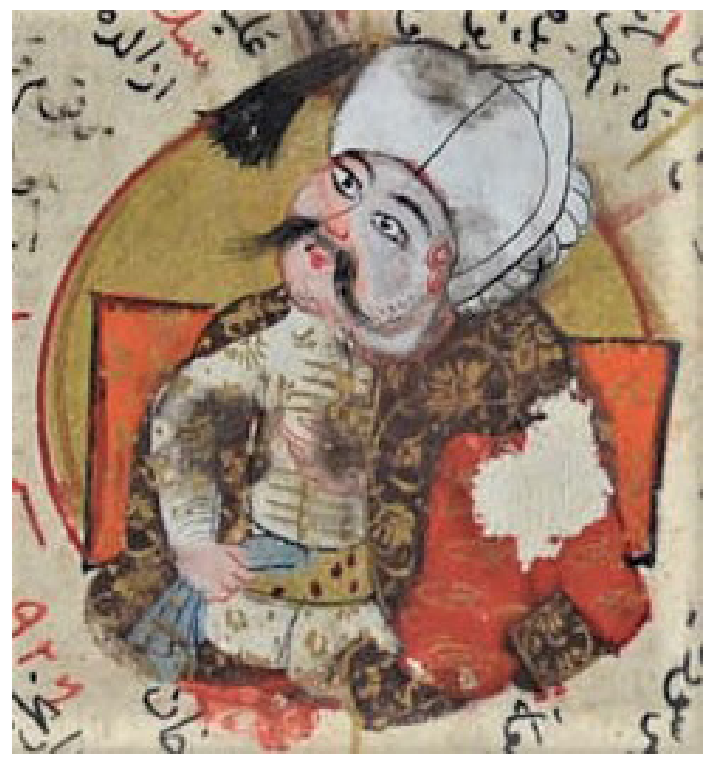

Görsel 5. Osmâniyân, Zübdetü târih, TSMK, H. 1591, 29b, (Aygan, 2017, s. 584)

Kimi kopyaların da birbirine üslup olarak daha yakın olduğu tespit edilmiştir. Topkapı Saray Müzesi Kütüphanesi'nde bulunan iki nüshada (TSMK A. 3110, TSMK H. 1624) karikatürize form daha az hissedilir. Baş-gövde oranları görece daha dengeli olan figürler ince ve uzunca betimlenmiştir. Bu iki nüshaya üslup açısından en yakın kopya Karlsruhe silsilenâmesidir (BL Rastatt 201). Daha az sayıda portre içermesine karşın daha canlı renkler kullanılmış, figürlerin yüzlerinde daha gerçekçi 
tonlar yakalanmışıı. Ayrıca silsile dizisinin bitiminden sonra III. Mehmed'in tam sayfa olarak taht üzerinde gösteren portresiyle yeniden ele alınması bu eserin sıra dışı özelliklerindendir (Resim 6).

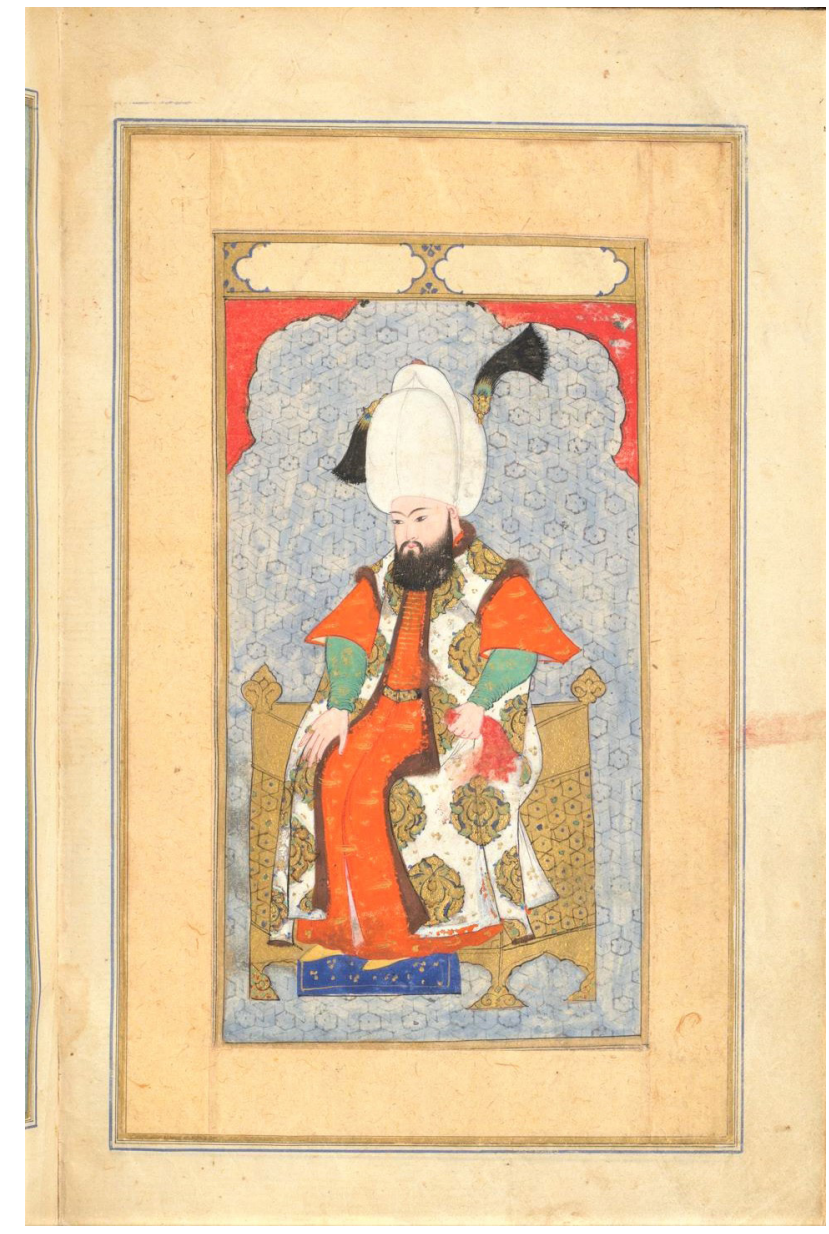

Görsel 6. III. Mehmed, Zübdetü târih, Karlsruhe Badische Landesbibliothek, Hs. Rastatt 201, y. 15b, (Aygan, 2017, s. 197)

Bağdat silsilenâmeleri arasında üslup olarak farklılık gösteren eserlerden biri kuşkusuz Stuttgart Silsilenâmesidir (Stuttgart, Linden Museum Inv. Nr. VI. A1 155). Günümüze dağınık sayfalar halinde ulaşan eserdeki portrelerde koyu tonlar tercih edilmiştir. Vücut-baş oranlarının görece dengeli olmasına karşın figürlerin genel fizyonomisinde ve kıyafetlerde detaycı çalışılmamıştır. Daha şaşırtıcı olan husus Osmanlı dizisinde yerleşik kalıpların dışına çıkıldığı izlenimi uyandırmasıdır. I. Murad'ın tombul vücudu, yanlara doğru uzayan bıyığı, I. Bayezid ve Il. Murad'ın gür siyah sakalları Nakkaş Osman kalıbından uzaklaşıldığını göstermektedir. Son madalyonda I. Ahmed'in sıra dışı biçimde kalabalık bir kompozisyonda ele alınışı silsilenâme 
geleneği açısından bir ilktir. Minyatürde sultan, at üstünde, ön ve arakasında hizmetkarlarıyla birlikte betimlenmiştir (Silsilenâme, 1603, y. 14a). Daire zeminindeki yeşil rengin üzerindeki çiçek detayları bir kır manzarası olduğunu göstermektedir (Resim 7).

Silsilenâme minyatürleri küçük bir daire içerisinde yer almasına karşın, resimler okuyucuya dairelere sığmayacak derecede zengin bir anlatım sunar. Metin, daire ve çeşitli şematik biçimlerle her biri özgün formla hazırlanan sayfalardaki tasvirler de buna eşlik eder. Âdem peygamberden başlamak üzere, eski peygamberler, Şehname'de anlatılan kadim hükümdarlar, Geçmiş Türk hükümdarları, İslam hanedanlarına mensup sultanlar ve Osmanlı dizisindeki padişahlar her biri kendine özgü ikonografik detaylarla

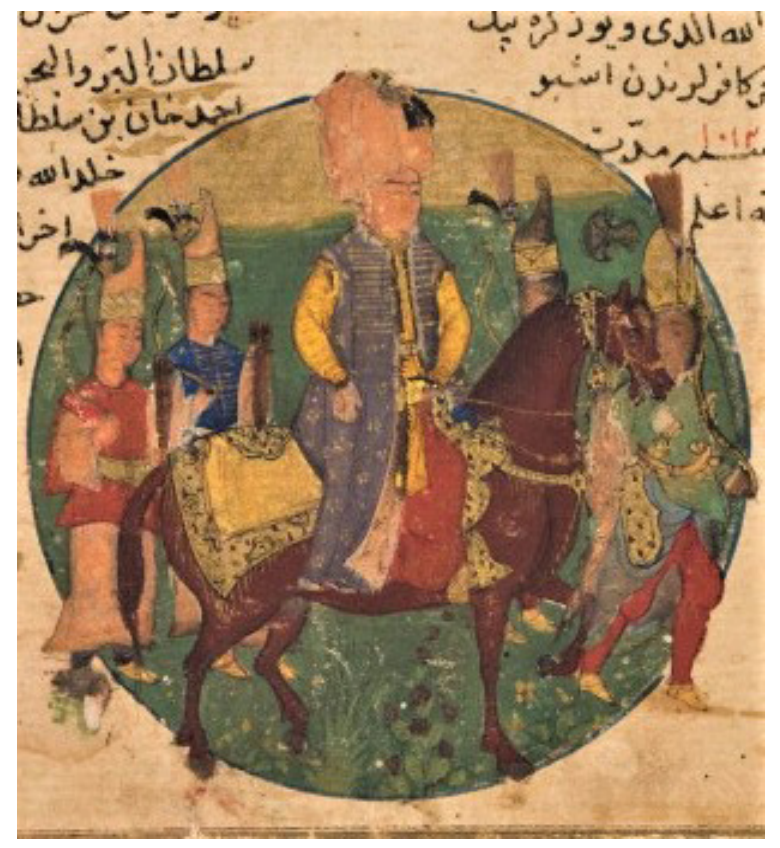

Görsel 7. I. Ahmed, Silsilenâme, 1603-1617, Stuttgart Linden Museum Inv. Nr. VI. A 1155 Nüshası, y. 14a, (Aygan, 2017, s. 204)

betimlenmiştir. Kadim peygamberler, uzun sakal, bol kıyafetler, başlarından yukarı doğru yükselen haleler ve yer yer ellerinde kitapla gösterilmiştir. Kur'an'da adı geçen peygamberlerin portrelerinde, o peygamberin kıssasını hatırlatacak bir imgeye başvurulmuştur. Örneğin Salih peygamber bir deve figürü ile birlikte tasvir edilmiştir. Peygamber, ellerini göğe doğru açmış vaziyettedir. Tasvirde Salih Peygamberin Tanrı'dan yardım istemesi ve Tanrı'nın duasını kabul ederek bir deve göndermesi temsil edilmiş, böylelikle kıssa, etkili bir görsel sunumla daire içerisine 


\section{$\operatorname{arts}=$}

sığdırılmıştır. ${ }^{5}$ Benzer bir örnekte Musa peygamber dairesinde görülen ejder başlı asâ, firavunun sihirbazlarıyla girmiş olduğu mücadeleyi anlatan kıssaya bir gönderme yapmaktadır. ${ }^{6}$ Peygamber tasvirleri arasında Süleyman ve Yusuf peygamberlerin betimleme tarzı dikka† çekicidir. Kur'an'da peygamberliklerinin yanı sıra hükümdar kimliğiyle de tanıtılan peygamberler (Kur'an-ı Kerim 2: 102; 27: 16; 38: 34). İslam resim sanatının yerleşik imgelerinin dışına çıkılarak birer sultan gibi gösterilmiştir. TSMK H. 1324 silsilenâmesinde Süleyman peygamber, başında kavuk, kolsuz kaftan, elinde tuttuğu mendille bir Osmanlı sultanından farksızdır.7 TSMK H. 1624 silsilenâmesindeki Yusuf peygamber de benzer biçimde hükümdarlık imgeleriyle karşımıza çıkar. ${ }^{8}$ Kıyafet biçiminin yanı sıra başındaki hükümdar tacı bu ikonografiyi pekiştirmiştir. Başından yukarı doğru yükselen hale ve elinde tuttuğu kitap peygamberliğine gönderme yapmış olsa da bunlar, hükümdar imgelerinin gerisinde kalmıştır.

İslam dönemi hanedanlarına gelindiğinde Abbasi dizisi hükümdarları dikkat çekmektedir. Beş sayfa olarak sağ taraftan ilerleyen dizideki hükümdarlar altın detayları olan siyah kaftan ve siyah sarıkla hemen fark edilir (Ayğan, 2017, s. 283). Silsilenâmelerde Abbasilerin kimliği gibi duran siyah rengin tercih edilmesi kaynaklara dayanmaktadır. Zira ilk Abbasi hareketinin siyah bayrak altında toplandığı, Abbasi halifelerinin siyah kıyafetler giydiği bilinmektedir. Hz. Muhammed ve Hz. Ali'nin sancaklarının da siyah renkte olması Abbasilerin bu tercihlerinin sebebi olarak gösterilmektedir (Üçok, 1968, s. 75; Yılmaz, 2008, s. 241).

Abbasi hanedanının Bağdatı sanatçılar tarafından özelleştirilmiş bir görsel kimlikle sunulmasının sebepleri olmalıdır. Bununla alakalı Bağdat'ın Abbasiler döneminde hilafet merkezi haline getirilmiş olmasıyla şehir üzerinden ortak bir aidiyet duygusunun sanatçılar tarafından geliştirilmiş olduğu düşünülebilir. Bunun yanı sıra Emevilere nispeten İslam dünyasının genelinde Abbasi hilâfetine karşı olumlu bir bakışın bulunması sanatçıların bu tutumunu açıklayan sebepler arasında gösterilebilir.

5 Silsilenâmelerdeki Salih peygamber tasvirleri için bkz. TSMK, H.1324, 21b; TSMK, H. 1591, 20b; TSMK, H.1624, 8b; TSMK, A. 31 10, 5b; DCBL, T. 423, 18b; BL, Hs. Rastatt 201, 5; iÜK T. 6092, 6 b.

6 Silsilenâmelerdeki Musa peygamber tasvirleri için bkz. TSMK, H. 1591, 22b; TSMK, H.1624, 7b; TSMK, A. 3110, 7b; DCBL, T. 423, 20b; BL, Hs. Rastatt 201, 7b; iÜK T. 6092, 8b.

7 Silsilenâmelerdeki Süleyman peygamber tasvirleri için bkz. TSMK, H. 1324, 23a; TSMK, H. 1591, 23a; TSMK, A. 3110 , 8a; DCBL, T. 423, 21a; BL, Hs. Rastatt 201, 8a; ï̈K T. 6092, 9 a.

8 Silsilenâmelerdeki Yusuf peygamber tasvirleri için bkZ. TSMK, H. 1591, 22a; TSMK, H.1624, 7a; TSMK, A. 3110, 7a; DCBL, T. 423, 20a; BL, Hs. Rastatt 201, 7a; iÜK T. 6092, 8a. 
Silsilenâmelerde Osmanlı öncesi Türk hanedanlarından Harezmşahlar, Gazneliler ve Selçuklular'a yer verilmiştir. ${ }^{9}$ Bu dizilerdeki Türk hükümdarlarının belirgin ikonografik hususiyetleri bulunmaktadır. Figürler genellikle orta boy veya seyrek sakallıdır. Kollu veya kolsuz kaftan giyiniktirler. Başlarındaysa genellikle dilimli ve uzun sorguçlu bir başlık bulunmaktadır. Kimi portrelerde ellerinde tuttukları mendil, kimi portrelerde kuşaklarındaki hançer hükümdar olduklarını gösteren ikonografik detaylardır. Bu gruptaki portreler arasında en dikkat çekici olan Sultan Melikşah portresidir. Silsilenâme nüshalarında genellikle dizilerde farklı karakterlerin portreleri tercih edilmişken, Selçuklu dizisinde Sultan Melikşah neredeyse tüm nüshalarda betimlenmiştir. Bunun bilinçli bir tercih olduğunu düşünmekteyiz. Zira silsilenâmelerdeki Melikşah portreleri ilginç biçimde birbirinin benzeridir. Çalışmamıza kaynaklık teşkil eden TSMK H. 1324, TSMK H. 1591, TSMK H. 1624, TSMK A. 3110 ve Dublin CBL T. 423 nüshalarında Sultan Melikşah, Osmanlı dizisindeki sultanlar gibi tasvir edilmiştir. Dolgun vücut hatları, gür ve siyah sakalı, kolsuz desenli kaftanı, bağdaş kurma oturuş pozisyonu ile bir Osmanlı sultanından farksızdır. Bir eli göğüs hizasında duran sultanın diğer eli mendil tutmaktadır (Resim 8). Melikşah'ın bir Osmanlı sultanı gibibetimlenmesi bizi Osmanlı dizinin başındaki giriş metnine yönlendirir. Metinde, Osmanlıların kuruluş döneminde Selçuklu hanedanı ile olan olumlu ilişkilerine değinilmiş ve onlardan sonra saltanata Osmanlıların layık olduğu düşüncesi vurgulanmıştır. ${ }^{10}$

\footnotetext{
9 Gazneli ve Harzemşah dizisindeki portreler için bkz. TSMK, H.1324, 25a; TSMK, H. 1591, 25a; TSMK, H.1624, 10a; TSMK, A. 31 10, 11 a; DCBL, T. 423, 23a; BL, Hs. Rastatt 201, 10a; iÜK T. 6092, 11 a; LM, Inv. Nr. VI A. 1155 . Selçuklu dizisindeki portreler için bkz. TSMK, H.1324, 25b; TSMK, H. 1591, 25b; TSMK, H. 1624, 10b; TSMK, A. 3110,11 b; DCBL, T. 423, 23b; BL, Hs. Rastatt 201, 10b; ï̈K T. 6092, 11 b; LM, Inv. Nr. VI A. 1155, 2.

10 Osmanlı dizisindeki metinde Selçuklu hanedanı ile Osman Gazi arasındaki ilişki şu şekilde anlatımıştır: "Bes Sultan Alaaddin vefat etti. Yerine Sultan Alaaddin bin Feramurz ki ol dahi âl-i Selçûkdur padişah oldi. Bu tarihte: 680. Ve ol esnada Tatar askeri dahi Ereğli'ye gelup, Sultan Alaaddin dahi Osman Han Gazi'yi kendi yerine kayim makam etti. Ve küffar canibine ğazaya gönderdi. Kendisi varıp Tatar'ı def' etti. Bu canibde dahi Osman Han Gazi gazalar edip ve nice kal'alar feth eyleyüp ve nice mal ve ganimet birle? Ahbar- beşaret Sultan Alaaddin'e gönderdi. Sultan Alaaddin dahi Osman Han Gazi'ye tabl ve alem verdi. Ve ol anda Osman Han Gazi varıp Bilecûk kal'ası feth edip aldı. Ve ol esnada Selçukilerin devleti tenezzül edip her vilayette onlardan kimse kalmadı fela cerem. Osman Han hem Kurun Saltanat olup asâr devlet ve uzmet onda hüveyda olup ayân memleket ona mutî' oldu ve ferman berdar oldular. Devlet ve saltanat berkarar kaldı. Ve rûz be rûz ve saat be saat der terakkî bûd ve hest ve padişah bade'l-yevm inşallah tealâ havâhed bûd." Bkz. Silsilenâme, TSMK H. 1324, y. 28b.
} 


\section{arts}

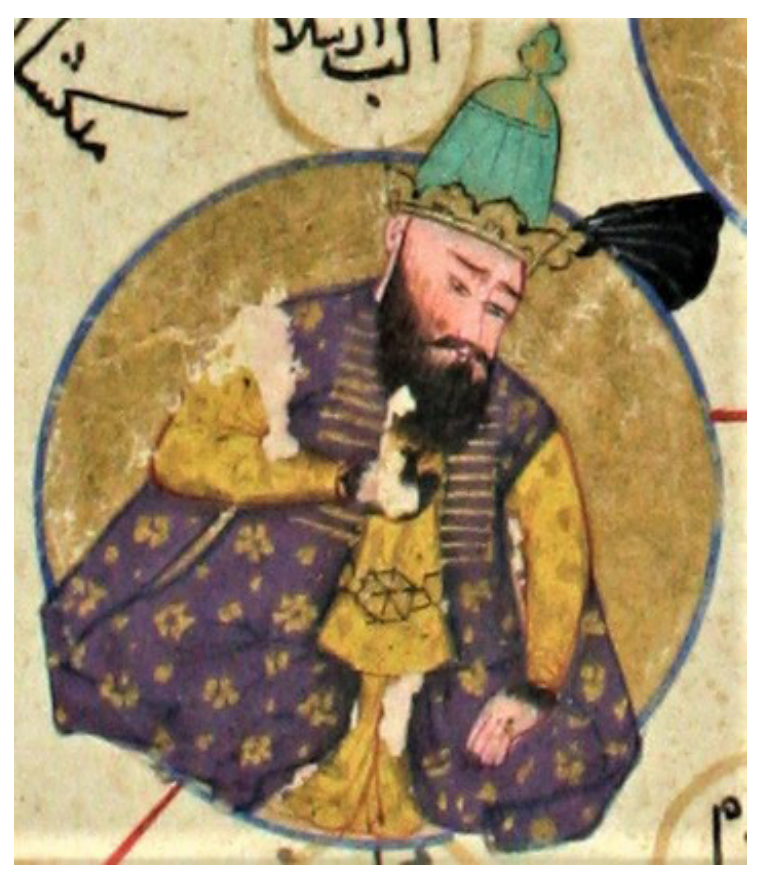

Görsel 8. Melikşah, Zübdetü târih, CBL T. 423, y. 23b (Aygan, 2017, s. 517)

\section{SONUÇ}

İslam dünyasında bir hanedan için hazırlanmış şematik biçimli soy ağaçlarının 13. yüzyıl sonlarından itibaren yaygınlaş̧ığı görülmektedir. 14. yüzylın başlarında ise IIhanlı sarayında Camiüt't-tevârih'e bir bölüm olarak tasarlanan Şuab-ı pençgana, bu türün resimli olarak tasarlanan ilk eseri olmuştur. Fakat eser planlandığı gibi tamamlanmamış, resim için ayrılan alanlar boş bırakıımıştır. Illk resimli örnek yaklaşık yüz yıl sonra yine bir Moğol hanedanı olan Timurlular tarafindan hazıllanacaktır. Timurlu şeceresi olarak bilinen eser içerdiği sultan portrelerindeki ikonografik özellikler ve tasarım biçimiyle sonraki eserlere örneklik teşkil etmiş olmalıdır.

Osmanlılarda ilk şematik örnek II. Bayezid dönemine ait olmasına karşın türün resimli biçimleri ilk olarak 16. yüzyll sonlarında Bağdat eyaletinde hazırlanan örneklerle karşımıza çıkmaktadır. Hanedanın kimliğine vurgu yapan bu eser türünün, saray dışındaki örneklerle hareketlik kazanması geleneğin tarihsel süreci bağlamında şaşırtıcı bir durumdur. Bağdat'ın jeopolitik konumu, Osmanlı ve Safevi arasındaki güç savaşının odağı haline gelmesi gibi sebepler bu hareketliliği tetikleyen görünür sebeplerdendir. Burada bizi ilgilendiren husus politik çekişmenin, resimli tarih yazıcllı̆̆ı içerisindeki bir türe ivme kazandırdığı gerçeğidir. Silsile türü eserlerin "bir özneye 
meşruiyet kazandırmak amacıyla geçmişle olan bağını temellendirme" gibi işlevi göz önüne alındığında hassas bir bölge olan Bağdat'†a egemenlik kurma adına bu eserlerin çoğalmış olması anlaşııı bir durumdur.

Bağdat silsilenâmeleri temel özellikleriyle İslam dünyasındaki arketiplerine sadıktır. Bir hanedan için hazırlanmış, o hanedanı dünya tarihinde öne çıkaran küçük boyutlu eserlerdir. Bu eserlerin bir özelliği de çoğunlukla büyük bir tarih eserinin bir fihristi veya özeti niteliğinde olmasıdır. Bu çerçeveden bakıldığında giriş metninde eserin adı olarak geçen "Zübdetü't-târih", III. Murad döneminde hazırlanan kökleri Tomar-ı Hümâyûn' a uzanan Zübdetü't-tevârih'e bir göndermedir. Aynı eser grubu içerisinde değerlendirilen Safevi yanlısı bir silsilenâmede eser isminin Cem-i Târih olarak nitelendirmesi de benzer biçimde Câmiü't-tevârih'e bir gönderme olmalıdır.

Bağdat grubu resimli silsilenâmelerinin Orta çağ örnekleriyle benzer olduğu bir konuda eserlerin kurgusal yapılarıdır. Bu eserler de özet bir giriş metni ve şematik soy ağaçlarını ihtiva eden basit bir yapıya sahiptir. Silsilenin asıl bölümü hanedanların ele alındığı şematik bölümdür. Bu sebeple bu bölümün anlaşlır olması eseri hazırlayanlar için bir övünç kaynağı sayılmaktaydı. Orta Çağdan bu yana birçok silsilede bunun bir problem olduğu ortadadır. Muhtemelen bu eserler ilk olarak rulo şeklinde tasarlandıkları için soy akışlarını takip etmek kolaydı. Kitap formatında hazırlandıklarında ise farklı sayfalarda, soylar arasındaki irtibatı kurmak ve okuyucuya anlaşıır hale getirmek zorlaşmıştı. Genel itibariyle kitap formatındaki eserler, rulo bir silsilenin sayfa sayfa kesilmiş biçimi gibi yatay olarak tasarlanmaktaydı. Soyların birbirinin devamı olduğunu göstermek için her hanedana ait dairelerin içleri aynı renge boyanmaktaydı.

Bağdat silsilenâmeleri temel kurgusal yapısı itibariyle önceki örneklere benzerlik gösterse de eserlerin tasarımı orijinal bir görünüm arz eder. Yatay sayfa tasarımı yerine dikey sayfa formatı eserleri rulo mantığından uzaklaştııp müstakil bir kitap kimliğine yaklaştırmıştır. Sayfalar dikkatle ayrı ayrı hazırlanmış, yeni bir diziye geçildiğinde farklı bir sayfadan başlamasına özen gösterilmiştir. Her hanedanın soy dizisi sayfa başından başlatılmış, hanedanla ilgili metinler dağınık biçimde değil, bir kutucuk içerisine yazılmıştır. Metinler, daireler ve soy dizileri sayfa içerisinde bütünlüğü sağlayacak biçimde yerleştirilmiştir. Bütün bu özellikler silsilenin anlaşılabilir olmasını 


\section{arts}

sağlamıştır.

Dikey sayfa tasarımıyla özelleştirilmiş Bağdat silsilenâmelerinin bir diğer özelliği de daireler içerisine portrelerin yapılmış olmasıdır. Osmanlı dizisinde Nakkaş Osman'ın kalıplarına uyulmuş, diğer dizilerde Bağdat üslubunun canlı figür tipleri daireler içerisine betimlenmiştir. Figürlerle birlikte onu karakterize eden ikonografik öğeler özenle seçilmiş ve daire içerisine yerleştirilmiştir. Kimi sayfalarda birbirine karşı duran portrelerde figürler birbirleriyle konuşuyormuş gibi tasvir edilmiştir. İkonografik detaylar ve monotonluktan uzak Bağdatı sanatçıların hareketli üslubu daireleri canlı hikayelere dönüştürmüştür.

Bu eser grubu, her ne kadar Osmanlı sarayının dışında hazırlanmış olsalar bile, eserlerde devlet adamlarının yoluyla olsa gerek merkezi yönetimin politik izlerine rastlanır. Şecere ilaveli nüshalardaki hattał kaydı istisna olmak üzere hiçbir nüshada hattat, musavvir veya müzehhip imzasına rastlanmaz. Eserlerin tamamı Osmanlı hanedanını dünya tarihi içerisinde kudretli yerini göstermeye adayan bir kimliğe sahiptir. Osmanlı sultanlarının portrelerinde Nakkaş Osman'ın modellerine uyulmuş olmanın yanı sıra eserlerin kısa bir dönem içerisinde dikey sayfa formatıyla resimlendirilerek iyi organize edilmiş standart tasarımlarla ortaya çıkışı da merkeziyetçi ifadenin neticesidir. Öyle ki üretimleri yaklaşık yirmi yıl devam edecek bu eser grubunun Bağdat'taki serüveni sona erdikten sonra aynı tasarımların 17. yüzyıl sonlarında Musavvir Hüseyin ile tekrar sistematik biçimde denenmiş olması hatta 19. yüzyıldan sonra bile devam ettirilmesi Osmanlıların 16. yüzyılda birçok alanda standartlaşmasının etkileriyle açıklanabilir.

\section{KAYNAKÇA}

Ayğan, A. (2017). Osmanlıarda silsile geleneği ve resimli hanedan silsilenâmeleri. (Yayımlanmamış Doktora Tezi). Mimar Sinan Güzel Sanatlar Üniversitesi Sosyal Bilimler Enstitüsü. İstanbul.

Babinger, F. (1982). Osmanlı tarih yazarları ve eserleri. Ankara: Kültür ve Turizm Bakanlığı.

Bağcl, S. (2000). Elyazmalarından albümlere: Ill. Mehmed. Padişahın Portresi: Tesavir-i Al-i Osman. İstanbul: Türkiye İş Bankası.

Bağcl, S. (2014). Presenting Va $\square \square$ ăl Kalender's Works: The Prefaces of Three 
Ottoman Albums. Muqarnas, 30(1), s. 255-313.

Bağcı, S., Çağman F., Renda, G. ve Tanındı Z. (2006). Osmanlı Resim Sanatı. İstanbul: Kültür ve Turizm Bakanlığı.

Bayâtî, Hasan bin Mahmûd. (1008). Câm-ı Cem-i Âyîn.

Bayram, S. (2004). Ankara Etnografya Müzesi'nde Bulunan Silsile-Nâme. Vakıflar Dergisi, 28, 315-63.

Binbaş, Illker E. (2011). Structure and Function of the "Genealogical Tree" in Islamic Historiography. Evrim Illker B., Nurten K. (ed.) Horizons of the World: Festschrift for Isenbike Togan (465-544). İstanbul: İthaki.

Cem-i târih, (†.y). AEM nr. 8457.

Çağman, F. (1979). XVI. Yüzyıl Sonlarında Mevlevi Dergahlarında Gelişen Bir Minyatür Okulu (651-77). I. Milletlerarası Türkoloji Kongresi. İstanbul: Türkiyat.

Çağman, F. ve Tanındı Z. (2005). Tarikatlarda Resim ve Kitap Sanatı. Ahmet Yaşar O. (Ed.) Osmanlı Toplumunda Tasavvuf ve Sufiler: Kaynaklar-Doktrin-Ayin ve Erkan-Tarikatlar Edebiyat-Mimari-Güzel sanatlar-Modernizm (503-533). Ankara: Türk Tarih Kurumu.

Değirmenci, T. (2017). Bir Osmanlı Paşasının Padişahlık Rüyası: Sokulluzâde Hasan Paşa ve Resimli Dünya Tarihi. Osmanlı Araştırmaları, 49, 171-202.

Emecen, F. (1989). Kanûnî Süleyman Devri. Kenan S. (ed.) Doğuştan Günümüze Büyük İslam Tarihi, 10. cilt., (313-383). İstanbul: Çağ.

Eren, M. (2012). Hadis IIIminde Rical Bilgisi ve Kaynakları. İstanbul : Türkiye Diyanet Vakfı İslam Araştırmaları Merkezi (ISAM).

Fayda, M. (1995). Ensab. Türkiye Diyanet Vakfı İslam Ansiklopedisi (cilt 11, s. 244-49). İstanbul: TDV.

Firuzabadi, Ebü't-Tahir Mecdüddin Muhammed b. Yakub b. Muhammed. (1304). Kamus tercümesi, el-Okyanusü'l-basit fi tercümeti Kamusi'l-muhit. Cit 1. İstanbul: Matbaa-i Bahriye.

Gülcü, E. (1999). Osmanlı İaresinde Bağdat (1534-1623). (Yayımlanmamış Doktora Tezi). Fırat Üniversitesi Sosyal Bilimler Enstitüsü, Elazığ.

Halaçoğlu, Y. (1991). Bağdat. Türkiye Diyanet Vakfı İslam Ansiklopedisi (cilt 4, s. 441-442). İstanbul: TDV.

Işın, E. (2007). Osmanlı Modernleşme çağında Bir Muhafazakârın Portresi: Ali Emîrî Efendi. Ali Emiri Efendi ve Dünyası. İstanbul: Pera Müzesi.

Karatay, Fehmi E. (1961). Topkapı Sarayı Müzesi Kütüphanesi Türkçe Yazmalar 


\section{arts}

Kataloğu. Cilt 1. İstanbul: Topkapı Saray Müzesi.

Mahir, B. (2005). Osmanlı minyatür sanatı. İstanbul: Kabalcı.

Milstein, R. (1990). Miniature painting in Ottoman Baghdad. Costa Mesa: Mazda.

Önkal, A. (1990). Araplarda Ensâb illmi ve İslâm Tarihi Açısından Önemi. Selçuk Üniversitesi llâhiyat Fakültesi Dergisi, III, s. 117-31.

Pakalın, Mehmet Z. (1983). Osmanlı tarih deyimleri ve terimleri sözlüğü. cilt 3. Ankara: Milli Eğitim Bakanlığı.

Renda, G. (1984). Ankara Etnografya Müzesindeki 8457 No'lu Silsilenâme Üzerine Bazı Düşünceler. Kemal Çığ'a Armağan (s.175-202). İstanbul: Topkapı Sarayı Müzesi Müdürlüğü.

"Silsilenâme". (†.y). SLM VLA 1155.

Szombathy, z. (2003). The roots of Arabic genealogy: a study in historical anthropology. Piliscsaba: The Avicenna Institute of Middle Eastern Studies.

Tanındı, Z. (2001). Osmanlı Yönetimindeki Eyaletlerde Kitap Sanatı. Ortadoğu'da Osmanlı Dönemi Kültür İzleri Uluslararası Bilgi Şöleni Bildirileri (Hatay 2527 Ekim, 2000). (Cilt 2 , s. 501-508). Ankara: Atatürk Kültür, Dil ve Tarih Yüksek Kurumu Atatürk Kültür Merkezi.

Tayşi, M. S. (1989). Ali Emîrî. Türkiye Diyanet Vakfı İslam Ansiklopedisi, cili 2, s. 390-91. İstanbul: TDV.

Tosun, N. (2009). Silsile. Türkiye Diyanet Vakfı İslam Ansiklopedisi, cilt 37, s. 2067. İstanbul: TDV.

Uğur, M. (1992). Ansiklopedik Hadis Terimleri Sözlüğü. Ankara : Türkiye Diyanet Vakfı.

Uzunçarşılı, İsmail H. (2011). Osmanlı Tarihi: Istanbul'un Fethinden Kanuni Sultan Süleyman'ın Ölümüne Kadar. Cilt 2. Ankara: Türk Tarih Kurumu.

Üçok, B. (1968). İslam Tarihi: Emeviler-Abbasiler. Ankara: Ankara Üniversitesi Illahiyat Fakültesi.

Yazıcı, M. (2015). Sahabe Bilgisinin Tespiti. İstanbul: M.Ü. İlahiyat Fakültesi Vakfı.

Yılmaz, M. (2008). Emevi ve Abbasi Dönemi Resmi Kıyafetleri. Ondokuz Mayız Üniversitesi Ilahiyat Fakültesi Dergisi 26-27, s. 237-250.

Yusuf b. Abdüllatif. (1 176). Sübhatü'l-ahbâr, TSMK B. 193.

Zübdetü târih. (1597a). TSMK H. 1324.

Zübdetü târih. (1598). CBL T. 423. 


\section{arts}

Zübdetü târih. (1600). ï̈K T. 7364.

Zübdetü târih. (1597b). TSMK H. 1591. 